\title{
Piotr Gibas
}

\section{U NARODZIN POLITYKI NARODOWEJ W CHINACH}

Sun Yat-sen, Trzy zasady ludu, przekład Agnieszka Łobacz, Wydawnictwo Akademickie Sedno, Warszawa 2014, ss. 286.

Trzy zasady ludu Sun Yat-sena, w tłumaczeniu Agnieszki Łobacz, ze wstępem i opracowaniem Małgorzaty Ławacz i Krzysztofa Gawlikowskiego, to pozycja potrzebna i aktualna. Nie tylko przybliża ona polskiemu czytelnikowi jedną z najważniejszych postaci w historii Chin oraz niezwykle istotny okres kształtowania się państwowości nowoczesnych Chin na przełomie XIX i XX w., lecz przede wszystkim stanowi wprowadzenie w problematykę oraz klucz do zrozumienia procesów zachodzących w Chinach współczesnych.

Sun Yat-sen to postać na wskroś paradoksalna. Z jednej strony, podobnie jak Gandhi, był człowiekiem niespełnionym, który nigdy nie osiągnął w pełni zamierzonego zwycięstwa. Z drugiej jednak strony to właśnie on stworzył podwaliny nowego państwa chińskiego, doprowadzając do ostatecznego obalenia cesarstwa i powstania kulejącej i rozdartej, ale nowoczesnej i demokratycznej republiki. Do swoich celów dochodził Sun w sposób gwałtowny i radykalny. W przeciwieństwie do Gandhiego był bezkompromisowym rewolucjonistą, który nie tylko nie wyrzekł się przemocy, ale wręcz do niej nawoływał i propagował ją jako jedyną skuteczną drogę do zwycięstwa. Uchodził za niebezpiecznego awanturnika, a nawet bandytę. Jako ,podkładacz bomb” i organizator zamachów w dzisiejszych czasach zostałby zapewne uznany za terrorystę. Chociaż nie działał jak Gandhi, również nie przypominał Arafata ani tym bardziej Bin Ladena, lecz raczej romantycznego Kościuszkę, który domagał się praw i wolności dla swojego narodu. 
No właśnie - „,narodu” - pojęcie, które Sun jako jeden zpierwszych wprowadził i zdefiniował w kontekście chińskim. Bardziej niż do wyzwolenia się spod jarzma kolonializmu dążył do uwolnienia się Chińczyków od nich samych: do porzucenia skostniałej tradycji, za to do ukształtowania świadomości patriotycznej i zjednoczenia wokół idei narodowej. To Sun powołał do życia chiński nacjonalizm jako nowoczesny nurt polityczny i państwowotwórczy. Zanim pojawił się Sun, Chińczycy nie myśleli, że są narodem żyjącym w państwie o nazwie Chiny. Słusznie zatem Sun został uznany za ojca narodu. I tu kolejny paradoks: poza Chinami pozostaje on postacią praktycznie nieznaną, a jeśli już, to częstokroć postrzegany jest mylnie jako twórca tych „lepszych”, demokratycznych Chin na Tajwanie. Jako współzałożyciel Partii Nacjonalistycznej Kuomintang Sun kojarzony jest współcześnie głównie z tą wyspą. Niewiele osób na Zachodzie zdaje sobie sprawę, że obie partie chińskie - komunistyczna i nacjonalistyczna - powstały w tym samym okresie i przy pomocy tych samych instruktorów Kominternu przysłanych z komunistycznej Rosji, a sam Sun pozostawał pod silnym wpływem idei marksistowskich.

Kiedy prezydent Lech Wałęsa w 1997 r. odwiedził Tajwan, stwierdził, że to „te dobre Chiny”, w zamyśle w odróżnieniu od tych „złych,” czyli komunistycznych. Co prawda nasz pokojowy noblista często wygłasza zdania, delikatnie mówiąc, szokujące, jak o sadzaniu homoseksualistów ,za murem” albo o potrzebie wyposażenia polskiej armii w broń jądrową. W tym jednak konkretnym przypadku wypowiedź Wałęsy wypływa nie tylko z jego własnego i nie zawsze przemyślanego spojrzenia na świat, lecz wpisuje się w ogólnie przyjętą w Polsce retorykę i odzwierciedla sposób postrzegania Chin, który wynika ze zwyczajnej niewiedzy albo oparty jest na fobiach i stereotypach. Chiny oczywiście nie dzielą się na dobre i złe. Kwestia ich jedności jest niezwykle skomplikowana, jeśli jednak chodzi o Sun Yat-sena, to jest on w tym przypadku postacią, która zdecydowanie łączy, a nie dzieli Chińczyków, inie wolno go utożsamiać tylko zjedną opcją polityczną.

System polityczny Republiki Chińskiej na Tajwanie jest oparty przynajmniej w teorii na założeniach Trzech zasad ludu Sun Yat-sena właśnie, a podobizny Suna znajdują się na banknotach waluty tajwańskiej. Na banknotach w ChRL widnieje nadal Mao Zedong, ale Sun Yat-sen jest oficjalnie uznaną i szanowaną postacią (vide mauzoleum w Nankinie, tudzież uniwersytet w Kantonie). Oprócz zwyczajnej symboliki jednak rząd i partia w Chinach Ludowych coraz częściej i coraz oficjalniej sięgają do doktryny Suna, o czym zresztą wspomina Krzysztof Gawlikowski we wprowadzeniu do pierwszego polskiego wydania Trzech zasad ludu. Doktryna ta, z założenia nacjonalistyczna, ale jednocześnie przesiąknięta marksizmem, nie tylko nie stała się anachroniczna, lecz okazuje się budulcem państwowości chińskiej w XXI w. Po raz kolejny, a może wciąż, idee Suna stanowią składnik jedności Chin. Nastepny zatem paradoks: postać identyfikowana znacjonalistyczną Re- 
publiką Chińską jest tak naprawdę pomysłodawcą doktryny państwa przynajmniej znazwy komunistycznego. Przy tym nie jest to oznaka powrotu ChRL do korzeni przedkomunistycznych, wręcz przeciwnie - to utrwalenie starych i tworzenie nowych fundamentów w kraju z dopiero rodzącą się świadomością, który teraz zaczyna budować przyszłość.

Dlatego Trzy zasady ludu to dzieło niezbędne do zrozumienia procesów zachodzących w dzisiejszych Chinach, stanowi doskonałe wprowadzenie wich zakres ikontekst. Polskie wydanie tego tekstu to praca, która obiektywnie przedstawia dorobek Suna, burzy stereotypy oraz doskonale prezentuje jego rolę i znaczenie nie tylko w Chinach, lecz w historii powszechnej. Tekst ten to podstawowy materiał źródłowy niezbędny do zrozumienia i poznania współczesnych Chin. Praca zawiera pierwsze tłumaczenie na polski wykładów Suna, jak również bogate opracowanie - szczegółową biografię pióra Małgorzaty Ławacz oraz wyczerpującą analizę historyczną autorstwa Krzysztofa Gawlikowskiego. Lektura pozwala zatem zapoznać się nie tylko z ideami Suna, ale i zrozumieć wydarzenia, które miały miejsce w Chinach przełomu XIX i XX w. Publikacja ta stanowi istotny wkład w studia nad Chinami w Polsce. Jest to lektura nie tylko dla historyków i specjalistów, lecz również dla przeciętnego czytelnika, który pragnie zapoznać się z problematyką współczesnych Chin. 